\title{
Mimesis in Bible Didactics - an outline in the context of religious education
}

\begin{tabular}{|c|c|}
\hline \multicolumn{2}{|c|}{$\begin{array}{l}\text { Authors: } \\
\text { Mirjam Zimmermann } n^{1,2} \\
\text { Ruben Zimmermann }\end{array}$} \\
\hline $\begin{array}{l}\text { Affiliations: } \\
{ }^{1} \text { Faculty of The } \\
\text { University of Si } \\
\text { Germany }\end{array}$ & $\begin{array}{l}\text { ology, } \\
\text { iegen, }\end{array}$ \\
\hline $\begin{array}{l}{ }^{2} \text { Faculty of The } \\
\text { North-West Un } \\
\text { Potchefstroom } \\
\text { South Africa }\end{array}$ & $\begin{array}{l}\text { ology, } \\
\text { iversity, } \\
\text { Campus, }\end{array}$ \\
\hline $\begin{array}{l}{ }^{3} \text { Faculty of The } \\
\text { Johannes Gute } \\
\text { University, Ger }\end{array}$ & $\begin{array}{l}\text { elogy, } \\
\text { enberg } \\
\text { many }\end{array}$ \\
\hline $\begin{array}{l}{ }^{4} \text { Faculty of The } \\
\text { University of th } \\
\text { South Africa }\end{array}$ & $\begin{array}{l}\text { ology, } \\
\text { he Free State, }\end{array}$ \\
\hline $\begin{array}{l}\text { Note: } \\
\text { Prof. Mirjam Zi } \\
\text { is a research as } \\
\text { Faculty of Theo } \\
\text { West Universit }\end{array}$ & $\begin{array}{l}\text { immermann } \\
\text { ssociate in the } \\
\text { ology, North- } \\
\text { y, South Africa. }\end{array}$ \\
\hline $\begin{array}{l}\text { Corresponden } \\
\text { Mirjam Zimme }\end{array}$ & $\begin{array}{l}\text { ce to: } \\
\text { rrmann }\end{array}$ \\
\hline $\begin{array}{l}\text { Email: } \\
\text { zimmermann@ } \\
\text { uni-siegen.de }\end{array}$ & Devantheo. \\
\hline $\begin{array}{l}\text { Postal address } \\
\text { Philosophical F } \\
\text { University of Si } \\
\text { Siegen, Germar }\end{array}$ & $\begin{array}{l}\text { :aculty, } \\
\text { iegen, } 57068 \\
\text { ny }\end{array}$ \\
\hline $\begin{array}{l}\text { Dates: } \\
\text { Received: } 16 \mathrm{Ju} \\
\text { Accepted: } 20 \mathrm{O} \\
\text { Published: } 23 \mathrm{C}\end{array}$ & $\begin{array}{l}\text { uly } 2014 \\
\text { Oct. } 2014 \\
\text { Oct. } 2015\end{array}$ \\
\hline $\begin{array}{l}\text { How to cite thi } \\
\text { Zimmermann, } \\
\text { Zimmermann, } \\
\text { 'Mimesis Bible } \\
\text { An outline in th } \\
\text { of religious edu } \\
\text { HTS Teologiese } \\
\text { Theological Stu } \\
\text { Art. \#2785, } 6 \text { p } \\
\text { dx.doi.org/10.4 } \\
\text { v71i1.2785 }\end{array}$ & $\begin{array}{l}\text { is article: } \\
\text { M. \& } \\
\text { R., 2015, } \\
\text { Didactics: } \\
\text { he context } \\
\text { ucation', } \\
\text { Studies/ } \\
\text { udies 71(1), } \\
\text { ages. http:// } \\
\text { 4102/hts. }\end{array}$ \\
\hline 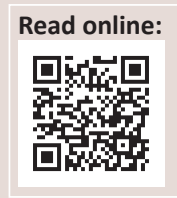 & $\begin{array}{l}\text { Scan this QR } \\
\text { code with your } \\
\text { smart phone or } \\
\text { mobile device } \\
\text { to read online. }\end{array}$ \\
\hline
\end{tabular}

'Mimesis' is a concept explored in Antiquity as well as in cultural history. It also plays an important role in the Bible. In this article we argue for 'mimesis' as a role model for Bible teaching in religious education. In the first part we give some insights into the concept of mimesis, drawing on ancient philosophers (Aristotle, Plato). 'Mimesis' does not denote a copy of a prescribed object; instead, the type of depiction and reference brings it into the present in an intensive, creative and productive way. In the second part we want to give some examples for how 'mimesis' is used in the Bible itself. Biblical tradition can be described as a 'mimetic process'. Furthermore, authors like Paul explicitly use the concept of 'mimesis', for example in his ethical admonition. Thus, the use of 'mimesis' in the Bible inspires directly our teaching on biblical genres, motifs and ways of thinking. The third part gives a draft of how the 'mimetic didactic' works, drawing on parables, Gospel writing, Johannine theology and coping with painful fate like Job. Mimetic hermeneutics transforms tradition in applying it into the contemporary situation. This can prove stimulating for contemporary contexts: mimesis is closely connected to tradition, but simultaneously encourages its transmission into the present day with astonishing variability and freedom.

\section{Introduction}

The goal of Bible didactics is the understanding of the Bible in a religious-pedagogical context. At this point, it is not specified whether the object of hermeneutics is primarily the Bible itself or whether the understanding refers to a self-knowledge of the reader in the light of the Bible or even to the act of understanding in the hermeneutical process with the Bible (see on this hermeneutic triangle Zimmermann \& Zimmermann 2013). Understanding can take place in various ways. It can be a cognitive process in which at first incomprehensible historic or linguistic issues are clarified or, through the affective appropriation of biblical texts, it can release the potential of holistic self and world discovery. Although unfamiliarity and incomprehension at times drive the hermeneutical process forward, in the 'hermeneutic circle' (Gadamer 1993) there always needs to be an expectation of meaning, an anticipatory desire for understanding and an advance of trust in addition to the classical preconceptions in order for understanding to succeed. It is this 'familiarity', the 'continuity of origin and tradition, in light of which all tradition is revealed' (Gadamer 1993:63) that should be incorporated in mimetic Bible didactics and made didactically productive. Such an 'engagement' with tradition - entering into the biblical text through reading, thinking and living - enables understanding not only of the text in how it came to be, but also of its 'true meaning', which includes the one who is understanding as elementary truth. The concept of 'mimesis' in particular helps to understand this process of applicative reading.

\section{'Imitation is natural to man from childhood' (Aristotle, Poetics 1448b)}

\section{What is mimesis? Terms and concepts Mimesis in theology}

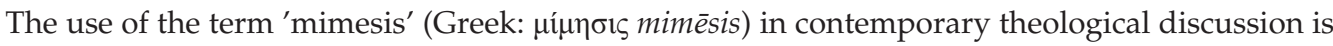
not new. The theses of René Girard, who traced social processes and social action back to a mimetic structure of consciousness (Girard 1972), have been widely received in systematic and practical theology. Similar resonance, particularly in the fields of text analysis and hermeneutics, was experienced by the trilogy Time and narrative by Paul Ricoeur, who chose 'mimesis' as the leading term for a phenomenological theory of text production and reception (Hähnel 2013; Ricoeur 1983:85). However, the term mimesis did not enter the religious-pedagogical discussion, neither through Girard's general anthropological conviction that human action is based on imitation, nor through Ricoeur's text- and lifeworld-based hermeneutics (Auerbach 1977:739-741). This is

Copyright: ( 2015 . The Authors. Licensee: AOSIS OpenJournals. This work is licensed under the Creative Commons Attribution License. 
particularly remarkable if we take into account that ancient discussion on mimesis explicitly included pedagogical aspects. The question of mimesis and the raising of children are central to the third book of Plato's Res Publica and reveals the philosopher's fundamental conviction that young people learn particularly through imitation. Plato argues that negative role models - as they are presented in the poetry he criticises - are to be avoided and instead that character is strengthened by the imitation of exemplary people (Plato, Res Publica: Book III:394d-398b; see also Büttner 2004:43). Aristotle found children's games to be explicitly mimetic as imitations of and practice for the problems of later life (Aristotle, Politica 1336a:30-35). In Poetica (1932), he regarded mimesis as an inherent trait of man 'from childhood' ( $\dot{\varepsilon} \kappa$ $\pi \alpha i \delta \omega v)$, which clearly sets him apart from other animals: 'From childhood men have an instinct for representation, and in this respect, differs from the other animals that he is far more imitative and learns his first lessons by representing things. And then there is the enjoyment people always get from representations' (Aristotle, Poetica 1448b).

Before we go down this pedagogical path accompanied by Bible-didactical intentions, we need a basic understanding of what 'mimesis' means and which aspects of the term can be used effectively in a bible-didactical concept.

\section{Terminological background}

To begin with, mimesis means imitation. However, even the attempt to identify the object and the process of imitation reveals many facets that have unfolded very differently in philosophical, aesthetic or social theory (Auerbach 2001; Eusterschulte 2001:1232-1294; Gebauer \& Wulf 1992; Potolsky 2006; Zapf 2004:459-460). It would, nevertheless, seem safe to start from the assumption that a relationship exists between the imitator and the one who is imitated, and that this relationship includes a temporal or logical dimension of the 'before' and 'after'. An existing person or object inspires or facilitates a process of mimesis. The details of the relationship can certainly vary; for example, both a sensual similarity and a correspondence on a non-sensual level can play a central role. Additionally, the accent can lie on the 'intentional construction of an analogy' (Gebauer \& Wulf 1992:9).

Looking first at the object that is to be imitated, mimesis is often equated with the imitation of nature: 'The Greek term

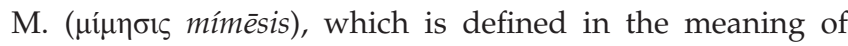
"the imitation of nature" (imitatio naturae) ...' (Eusterschulte 2001:1233). However, this reflects a specification originating with Aristotle that does not do justice to the breadth of the use of the term from its beginnings (see Gebauer \& Wulf 1992:46). Correspondingly, with his dramatic display, an actor (a mime) in the Doric theatre presents 'human life such "as it is"; [... he portrays] daily life' (Plato, Res Publica:392c). Here mimesis refers to the embodiment of a person, their behaviour and their character. As we can see from his criticism of poets in the third book of The Republic, Plato adds a further dimension. He criticises the poets because they violate the postulate of the 'depiction of truth' in their mimesis of heroes and gods. Thus, it is more than simply the imitation of an object or character. Mimesis includes the issue of the perception and depiction of reality in a more comprehensive sense. Even as early as Plato, mimesis was understood ethically, because the depiction is not random, but rather should be in a good or correct relationship to the imitated object. The supposition here is that the person or object being imitated is also worth imitating (Gebauer \& Wulf 1992:50). Mimesis can be good or bad; it has always had an implicit 'claim to truth'. However, Plato does not make his judgements according to the concepts of modern realism. Against the background of his metaphysical epistemology and image theory, imitation enables (or prohibits) participation in the idea of good. Correspondingly, role models should be imitated in a virtuous way so that mimesis is understood as a form of emulation that serves to improve character and soul.

If we turn to the mediality of mimesis we must ask how, with what materials and in what way imitation takes place. The ancient discussion concentrated on the areas of handicrafts, music, art, drama, and literature. Plato was critical of the mimesis of poets, and in Poetica, Aristotle developed a theory of poetic mimesis that retains its influence even today. Correspondingly, Poetica begins with the sentence referring to all possible forms of poetry and music: they 'may

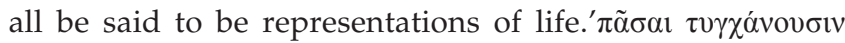

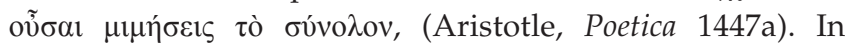
contrast, for Aristotle, poetic mimesis' claim to truth was not characterised by participation in the idea of the good nor by the exact imitation of people and historical events. Instead, poetic mimesis was successful in the depiction of a well-structured plot or a coherent structure of action as in a tragedy. 'M[imesis] depicts a plot whose unity, consistency and plausibility is based on general, causal principles of real events' (Eusterschulte 2001:1241). According to Aristotle, the task of literature is not to portray what has really happened, but what could happen according to the rules of necessity and probability: 'In character-drawing just as much as in the arrangement of the incidents one should

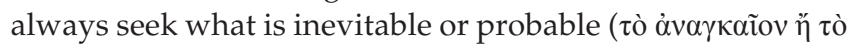
Eikós)' (Aristotle, Poetica 1454a:34f.). Mimesis thus extends its function from being purely a copy and a depiction

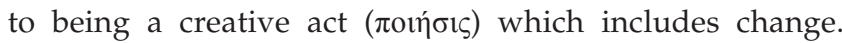
The character traits of people, for example, are 'recreated similarly but with greater beauty' in tragedy (Aristotle, Poetica 1454b:11). 'Mimesis produces fiction. [...] the poet creates something that did not previously exist and for which there are no models' (Gebauer \& Wulf 1992:84). The remaining difference between imitation and the imitated object, which up to now was considered to be a deficit, is now recognised by Aristotle as a creative and productive moment in the act of mimesis. Mimesis is no longer only reproduction, but also the production and creation of something new. The imitator thus matches nature, which also creates something new.

Aristotle also points out that mimesis must be judged according to its impact (see Potolsky 2006:43-46). Mimesis 
is successful, for example, when a tragedy triggers feelings in the audience: 'since tragedy represents ( $\mu$ í $\mu \eta \iota \varsigma$ ) not only a complete action but also incidents that cause fear and pity, and this happens most of all when the incidents are unexpected and yet one is a consequence of the other. For in that way the incidents will cause more amazement than if they happened mechanically and accidentally, since the most amazing accidental occurrences are those which seem to have been providential' ( Poetica 1452a). Above all, mimesis arouses joy, whether it be sparked by the recognition of the object that is reproduced or by the manner of depiction f.e. the execution, colour, characteristic (Aristotle, Poetica 1448b:15-20; Aristoteles, Rhetorica 1371b:5-6). Finally, the learning effect evoked by mimetic images can be the reason for joy: 'They [philosophers and all people] are pleased at the sight of images because by observing they try to learn and discover what each one is (ö $\tau 1$

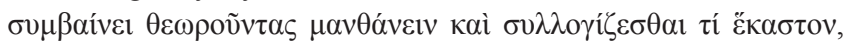

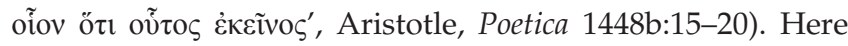
Aristotle describes mimesis as an effective aesthetic category in which the model character of mimesis has a direct impact on the recipient.

This brief outline of the ancient discussion has produced the following ideas, which can be adopted and developed further with regard to mimetic didactics:

- Mimesis is not a copy of a prescribed object reproduced in a 1:1 ratio. At the same time we can differentiate between successful and unsuccessful mimesis. For Plato the standard of this evaluation is the participation in truth.

- Mimesis is related to a 'pre-existing' object; however, the type of depiction and reference brings it into the present in an intensive, creative and productive way. In this way, there is a successful balance between traditio and innovatio.

- Mimesis has a cognitive and affective impact, whether it be on the imitator or on the recipient of the imitation. It thus triggers emotions (e.g. joy) and processes of recognition.

- Mimesis can be regarded as a process that brings about new acts of mimesis.

\section{'Follow my example!' (1 Cor 11:1) Fundamental elements of 'mimetic Bible didactics'}

\section{The Bible as a mimetic process}

Biblical scholarship has been able to demonstrate in many places that the biblical tradition itself can be described as a 'mimetic process'. This holds true for the storytelling of the Hebrew Bible (e.g. the deuteronomical historical work related to the Jahwist-Elohist narration), for the recording process of the prophets (e.g. the book of Isaiah) as well as for the Gospels or the micro-genres. The Jesus narrative in Mark is not simply copied by Luke; it is 'imitated' in a way that we can call 'mimetic' (Lk 1:1-3). On the one hand, the tradition is preserved with respect and deference and at the same time it is transferred creatively into the appropriate situation. Individual stories are also imitated, for example, when the story of the healing of the blind (Mk 10:46-52) is told in Matthew in two different ways (Mt 9:27-31; 20:29-34), although the exegesis as a whole agrees that the duplication in Matthew 9 in particular is to be attributed to the Evangelist (Luz 1996:58). Entire genres, such as Jesus' parable speech, can be imitated in order to lend the message of Christian ethics mimetic expression (e.g. Mt 21:28-32 and Mt 25:1-13, see R. Zimmermann 2009a:258-264).

The transmission of the faith message itself can be terminologically linked to 'mimesis'. In Paul's texts in particular, the apostle encourages his listeners to become

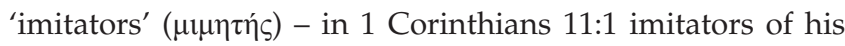
own person, as he was once an imitator of Christ (1 Th 1:6; 2:14; 1 Cor 4:16; Phlp 2:1-11; see Castelli 1991; Eastman 2008; Horn 2016). Paul challenges his addressees not only to imitate a particular behaviour (e.g. to take on suffering, 1 Th 2:14), but much more to adopt a form of behaviour. The mimesis of Paul's exemplary renunciation of monetary payment (see 1 Cor 9) does not mean that the addressees must also abstain from receiving payment but rather, in consideration of others, they must abstain from the freedom of eating meat sacrified to idols.

\section{Traditio and innovatio: Border crossings - emphasis}

The interpretation of the (Jewish) tradition in the light of the Christian faith caused for Paul the insight that it was possible to belong to the people of God without being tied to certain Jewish rituals such as circumcision. The Torah remained 'holy' and 'good'. However, the interpretation of the Torah with regard to Christ had shifted emphasis so clearly that, as of that point, it became possible to regard circumcision as superfluous. For those who might see a Jewish-Christian conflict looming here, there is another example to demonstrate that Paul was ultimately concerned with a certain type of interpreting the message, a hermeneutic and a mimetic application of God's truth. We can see this in the way that Paul uses Jesus' words, to which he explicitly refers in 1 Corinthians 7:10-11 and 9:14. He does not challenge their authority in principle in the argumentative context; however, their intention is transferred into the contemporary situation in such a way that a quick glance reveals a converse interpretation. Jesus' prohibition of divorce does not prevent Paul from agreeing to separation in mixed marriages (1 Cor 7:14) and he himself does not take advantage of the commandment regarding the receipt of payment for preaching (1 Cor 9:15, see Zimmermann \& Zimmermann 1996:83-100).

Thus, mimetic hermeneutics can convey tradition so far into the contemporary situation that aspects of tradition are transformed into their apparent opposite. This can prove stimulating for contemporary contexts: mimesis is closely connected to tradition, but simultaneously encourages it into the present day with astonishing variability and freedom. 


\section{Media connectivity and the aesthetics of biblical forms of language and thought}

'The medium is the message'. This wellknown sentence from M. McLuhan is also true concerning biblical texts. Message and medium are not to be separated. We believe that biblical texts cannot be reduced to one object (Oeming 2010:140-174) or basic motifs (Theissen 2003:131-137) without alienating or even destroying their messages. Such processes of abstraction are, of course, unavoidable. However, mimetic Bible didactics should be responsible for reminding us of the Bible's forms of language and thought, for depicting them in a way that has relevance for the present day and for updating them. Overlooking this mediality has often caused problems in interpretation. Reading the glorification of the creator as portrayed in Genesis 1:1-2; $4 \mathrm{a}$ as a historical 'report' or as a scientific explanation of the world disregards its specific form as religious poetry. Interpreting the title 'son of God' for Jesus using an ontological theory of God robs the familial metaphor of an intimate familial relationship. An analysis of the Gospel of John with regard to ethical norms and concrete instructions for action can completely disregard the impulse of 'narrative ethics' of the Fourth Gospel (see R. Zimmermann 2012b:133-170). Understanding requires a process of thinking, speaking and feeling one's way into the aesthetics of the texts. Mimetic Bible didactics attempt not only to understand the specific form of the biblical tradition, but also to incorporate it didactically and methodologically. The message of the Bible cannot be understood beyond or outside of its mediality, but only 'in, with and under' its forms of language and thought.

\section{Mimetic concretion: Who and what should be imitated and how should it be done?}

The goal of mimetic didactics is to turn students themselves into 'mimetai' or active imitators. They should not merely understand the mimesis of a biblical author or commentator. In doing this, various aspects can be imitated. A biblical character can become a faith role model not only in its virtuosity but also in its ambivalence (e.g. Jacob as the imposter and the blessed one). A single genre or even an entire book of the Bible can be received mimetically. Or there is a specific manner of thinking and speaking, for example narratively, metaphorically or dialectically, with which a theological problem is discussed. The form of the mimetic act is equal to and greater than the variety of the biblical texts themselves. Mimesis is different from role learning and copying. There is always a creative process of transferral, implementation and realisation. Mimesis makes it possible to tune into biblical theologising in a way that leads to the further development of thought and word. The goal of the mimetic process is to create a space for the lively experience of fundamental biblical truths. Or to put it more conservatively: the interactive mimetic event allows us, whilst we contemporarily hear, speak and understand the 'word of God', to simultaneously recognise continuity back to the biblical hearing, speaking and understanding.

\section{'I have set you an example ...' (Jn 13:15): Outlines of the application of mimetic Bible didactics \\ Mimetic Bible didactics with Jesus' parables}

Jesus' parables can be understood didactically in numerous ways (see R. Zimmermann 2013:196-201). The particular value of mimetic parable didactics is that the mediality, the literary form of the texts and the theological reflexivity become productive.

A parable is a fictional narrative text of which the narrative content is realistic but also understood metaphorically due to transfer signals (R. Zimmermann 2015:137-150). The parable unfolds its so called 'appeal structure' in the respective context (R. Zimmermann 2007:3-46; R. Zimmermann 2009b:170-173). Individual aspects of this parable definition can be incorporated didactically. The narration can stimulate the retelling, modifying and passing on of the New Testament texts. In mimetic replication, the basic elements of poetic mimesis (Aristotle) - the structures, the stringency of the plot, the constellation of characters etc. - are penetrated. Parables are not historical (factual) narratives; instead they portray events and problems in an intense and concentrated way. This fictionality challenges one to continue working creatively by, for example, thinking of new visions for the Kingdom of God or other stories. Because parables describe realistic events, they also invite us to search for examples in the real world experiences of children and youth that are suitable as source domains for religious statements. Parables are also metaphorical texts that transfer real occurrences into the religious field. The idea is not only to capture and discuss daily life with regard to its problems, but also to transfer it figuratively to God's world. What does a conflict between siblings (Lk 15:11-31) or the treatment of animals (Lk 15:17) have to do with God? How can I reflect on my lifeworld (terminus technicus) in relation to the reality of God? Does this way of thinking lead me to sense the entity of a God in the human world or rather Jesus, who in his role of parable teller becomes a parable of God? 'Capturing the contents of the theology of the parables requires that we read them and that we enter into their world in order to understand them from the inside out' (R. Zimmermann 2007:12). Mimetic didactics goes one step further. In order to understand Jesus' parables, we are encouraged to record their specific form of language and thought in creative writing. Mimetic parable didactics invites us to invent our own parables that both incorporate all aspects of the biblical parables and also present them in a new way. This process not only imitates biblical parable material, but also dares to speak of God in a new way using the images of the world. Mimesis makes it possible to go far beyond the biblical parable worlds (for example, to include the electronic world and the world of media). 
Of course, not every finger exercise tested in this way becomes a masterpiece and would have to put up with the criticism that Plato levelled toward the 'untrue, superficial' mimetic creations of the poets (3rd Book of The Republic). However, the attempt at God's parable-like speech can capture a deep insight, an 'elementary truth' and remains linked to the opportunities and limits of the exegetic freedom of children.

\section{Further examples}

There is an entire series of texts and characters particularly suited to mimetic Bible didactics, which we can outline here.

Analysing the complex structure and long speeches of the book of Job is certainly not enticing to students. It is also difficult for students to put themselves in the position of such a man of suffering. However, when they use this material to understand the problems suffered by their peers and then mimetically write their own book of Job (the task is to reproduce the structure of the book using the background story and dialogues or individual components see M. Zimmermann 2011:28-33) they participate directly in the theological processing of suffering.

By means of creative writing workshops, young people can also be introduced into the process of the Jesus tradition and can themselves become Gospel writers (M. Zimmermann 2012a:8-13). They can find their way into this alien time period more easily by using characters from Jesus' time with whom they can identify. However, it is not about baking unleavened bread or weaving Jewish clothing as in classical action-oriented lessons. Instead, by imitating Jesus' contemporaries, the students themselves become present-day witnesses who listen to, collect and also retell the Jesus stories in their own writing. Well-known synoptic Jesus stories are preserved but also changed and told anew in the young people's perspectives. This enables them to experience an identificatory process of faith discussion about Jesus' teachings and actions, and makes them sensible to the synoptic problem through the differing results.

Because of its diverse aspects of aesthetic impact, the Gospel of John is also well suited to mimetic didactics (see R. Zimmermann 2012a:6-9). Sophisticatedly developed narrative characters (see R. Zimmermann 2014:1-34; Hunt, Tolmie \& Zimmermann 2013:1-45), such as Nicodemus (Jn 3) or the Samaritan woman (Jn 4) and their long dialogues about 'God and the world' (Jn 3:9) or life and death (Jn 11) invite the readers themselves to enter into the dialogue using character mimesis. The Johannine misunderstandings can also be imitated as catalysts for the cognitive process. The form of paradoxical theological thought and language in the Fourth Gospel can be incorporated mimetically, for example, in theological Johannine discourse for young people (see M. Zimmermann 2012b:200-205). Ultimately, the figurative wealth of the metaphorical Christology in the Fourth Gospel would be undermined by a purely religio-historical (e.g. on the titles) or dogmatic (e.g. dual nature of Person of Christ) transmission, whereas the aesthetic depiction of a Christ mosaic (e.g. in the style of Robert Silva's foto mosaic) assists in the medial imitation of the Christological process of reflection in the Fourth Gospel.

These few suggestions alone demonstrate that mimetic Bible didactics can be implemented in many different ways. Entire works (such as the book of Job) or individual types of text (the parables) can be imitated. We can also reproduce the process of transferring and transmitting the message (Gospel writing) or the form of theological language and thought (Johannine theology). Mimetic Bible didactics is closely linked to tradition and thus attempts to incorporate both the content of biblical texts and their aesthetics and mediality. At the same time, however, it is an invitation to a broad and open process of imitation that, in its quest for truth, leaves the past fixation on the biblical message far behind it in favour of its contemporary vitality.

\section{Acknowledgements Competing interests}

The authors declare that they have no financial or personal relationship(s) that may have inappropriately influenced them in writing this article.

\section{Authors' contributions}

Both authors, M.Z. (University of Siegen) and R.Z. (Johannes Gutenberg University) contributed equally to the writing of this article.

\section{References}

Aristotle, 1932, Poetics, transl. W.H. Fyfe, Harvard University Press, Cambridge, MA/ William Heinemann, London.

Auerbach, E., 1977, 'Wie erzählt die Bibel?', Katechetische Blätter 102, 739-741.

Auerbach, E., 2001, Mimesis: Dargestellte Wirklichkeit in der abendländischen Literatur, 10th edn., Mohr Siebeck, Tübingen.

Büttner, St., 2004, 'Literatur und Mimesis bei Platon', in J. Schönert \& U. Zeuch (Hrsg.), Mimesis. Repräsentation. Imagination: Literaturtheoretische Positionen von Aristoteles bis zum Ende des 8. Jahrhunderts, pp. 31-63, De Gruyter, Berlin.

Castelli, E.A., 1991, Imitating Paul: A discourse of power, Westminster John Knox, Louisville, $\mathrm{KY}$.

Eastman, S., 2008, 'Imitating Christ imitating us: Paul's educational project in Philippians', in J.R. Wagner, C.K. Rowe \& A.K. Grieb (eds.). The word leaps the gap: Essays on scripture and theology in honour of Richard B. Hays, pp. 427-451 gap: Essays on scripture and the
Eerdmans, Grand Rapids, MI.

Eusterschulte, A., 2001, 'Mimesis', HWR 5, 1232-1294.

Gadamer, H.-G, 1993, 'Vom Zirkel des Verstehens', in H.-G. Gadamer (ed.), Hermeneutik II. Wahrheit und Methode, 2nd edn., pp. 57-65, Mohr Siebeck, Tübingen.

Gebauer, G. \& Wulf, C. (eds.), 1992, Mimesis: Kultur - Kunst - Gesellschaft, Rowohlt Verlag, Reinbek.

Girard, G., 1972, La violence et le sacré, Éditions Bernard Grasset, Paris.

Hähnel, M. (ed.), 2013, Memoria und Mimesis: Paul Ricoeur zum 100. Geburtstag, Text und Dialog Verlag, Dresden.

Horn, F.W. 2016, 'Mimetische Ethik im Neuen Testament', in U. Volp, F.W. Horn \& R. Zimmermann (Hrsg.), Metapher - Narratio - Mimesis - Doxologie. Begründungsformen frühchristlicher und antiker Ethik. (Contexts and norms of New Testament ethics, vol. 6).

Hunt, S.A., Tolmie, D.F. \& Zimmermann, R., 2013, 'An introduction to character and characterization in John and related New Testament literature', in S.A. Hunt, D.F. Tolmie \& R. Zimmermann (eds.), Character studies in the fourth Gospel. Narrative approaches to seventy figures in John, pp. 1-43, Mohr Siebeck, Tübingen.

Kille, D.A., 2007, 'Imitating Christ: Jesus as model in cognitive learning theory', in J.H. Ellens (ed.), Text and community: Essays in memory of Bruce M. Metzger, pp. 251-263, Sheffield Phoenix Press, Sheffield. 
Luz, U., 1996, Das Evangelium nach Matthäus, Vol. 2: Mt 8-17, EvangelischKatholischer Kommentar I/2, 2nd edn., Neukirchener Verlag, Neukirchen-Vluyn.

Oeming, M., 2010, Biblische Hermeneutik: Eine Einführung, 3rd edn., Wissenschaftliche Buchgesellschaft, Darmstadt.

Potolsky, M., 2006, Mimesis, Routledge, New York, NY.

Ricoeur, P., 1983, Temps et récit, Tome I-III, Seuil, Paris.

Stuhlmacher, P., 1986, Vom Verstehen des Neuen Testaments: Eine Hermeneutik, 2ndedn. Vandenhoeck \& Ruprecht, Göttingen. http://dx.doi.org/10.13109/9783666513664

Theissen, G., 2003, Zur Bibel motivieren. Aufgaben, Inhalte und Methoden einer offenen Bibeldidaktik, Gütersloher Verlagshaus, Gütersloh.

Zapf, H., 2004, 'Mimesis', in A. Nünning (Hrsg.), Lexikon Literatur- und Kulturtheorie 3rd edn., pp. 459-460, Metzler Verlag, Stuttgart.

Zimmermann, M., 2011, 'Hiob reloaded - nach Gerechtigkeit fragen. Schülerinnen und Schüler schreiben moderne Hiob-Erzählungen', Religion 5-10(4), 28-33.

Zimmermann, M., 2012a, 'Faszination Jesus. Kreatives Schreiben zu biblischen Texten', Religion 5-10(4), 8-13.

Zimmermann, M., 2012b, 'Das “johanneische Gespräch" als Leitbild eines Theologisierens mit Kindern', in M. Zimmermann (Hrsg.), Kindertheologie als Theologische Kompetenz von Kindern. Grundlagen, Methodik und Ziel kindertheologischer Forschung am Beispiel der Deutung des Todes Jesu, 2nd edn., pp. 200-205, Neukirchener Verlag, Neukirc hen-Vluyn.

Zimmermann, R., 2007, 'Die Gleichnisse Jesu. Eine Leseanleitung zum Kompendium', in R. Zimmermann (Hrsg.), Die Gleichnisse Jesu, pp. 3-46, Gütersloher Verlagshaus, Gütersloh.

Zimmermann, R., 2009a, 'Die Ethico-Ästhetik der Gleichnisse Jesu. Ethik durch literarische Ästhetik am Beispiel der Parabeln im Matthäus-Evangelium', in F.W. Horn \& R. Zimmermann (Hrsg.) Jenseits von Indikativ und Imperativ, pp. 235-265, Mohr Siebeck, Tübingen. (Contexts and norms of New Testament ethics, vol. 1)
Zimmermann, R., 2009b, 'How to understand the parables of Jesus? A paradigm shift in parable exegesis', Acta Theologica 43, 157-182. http://dx.doi.org/10.4314/ actat.v29i1.44175

Zimmermann, R., 2012a, 'Der didaktische Johannes. Neuere Trends in der Johannesforschung und ihre didaktischen Implikationen - ein Beitrag zur mimetischen Bibeldidaktik', entwurf (2), 6-9.

Zimmermann, R., 2012b, 'Narrative Ethik im Johannesevangelium am Beispiel der Lazarus-Perikope Joh $11^{\prime}$, in J. Frey \& U. Poplutz (Hrsg.), Narrativität und Theologie im Johannesevangelium, pp. 133-170, Neukirchener Verlag, Neukirchen-Vluyn.

Zimmermann, R., 2013, 'Gleichnisse/Parabeln Jesu', in M. Zimmermann \& R. Zimmermann (Hrsg.), Handbuch Bibeldidaktik, pp. 196-201, Mohr Siebeck, Tübingen.

Zimmermann, R., 2014, 'Figurenanalyse im Johannesevangelium. Ein Beitrag zu Sinn und Wahrheit narratologischer Exegese', ZNW 105, 20-53.

Zimmermann, R., 2015, Puzzling the Parables of Jesus. Methods and interpretation, Augsburg Fortress, Minneapolis, MN.

Zimmermann, M. \& Zimmermann, R., 1996, 'Zitation, Kontradiktion oder Applikation? Die Jesuslogien in 1 Kor 7,10f. und 9:14: Traditionsgeschichtliche Verankerung und paulinische Interpretation', ZNW (87), 83-100.

Zimmermann, M. \& Zimmermann, R., 2005, 'Hermeneutische Kompetenz und Bibeldidaktik. Durch Unverständnis der Bibel das Verstehen lernen', Glauben und Lernen (20), 72-87.

Zimmermann, M. \& Zimmermann, R., 2006, 'Bibel verstehen lernen', in M. Wermke, G. Adam \& M. Rothgangel (Hrsg.), Kompendium Religionspädagogik, pp. 219-227, Vandenhoeck \& Ruprecht, Göttingen.

Zimmermann, M. \& Zimmermann, R., 2013, 'Hinführung und Leseanleitung', in M. Zimmermann \& R. Zimmermann (Hrsg.), Handbuch Bibeldidaktik, pp. 1-21, Mohr Siebeck, Tübingen. 